\title{
Histochemical study of $\beta$-glucuronidase in the rat uterus during implantation and pseudopregnancy*
}

\author{
S. K. Roy†, Jayasree Sengupta and S. K. Manchanda \\ Department of Physiology, All India Institute of Medical Sciences, New Delhi-110029, India
}

\begin{abstract}
Summary. On Day 5 of pregnancy and pseudopregnancy, $\beta$-glucuronidase activity in pseudopregnant uteri and in the inter-implantation zones from pregnant animals was found mainly in stromal and glandular epithelial cells. The luminal epithelium also showed an intense enzyme-positive reaction, particularly in the apical regions of these cells. Blastocyst attachment was associated with marked depletion of $\beta$-glucuronidase activity from epithelial cells lying adjacent to the blastocyst, suggesting a possible involvement of this lysosomal enzyme in the blastocyst-endometrium attachment reaction.
\end{abstract}

\section{Introduction}

Attachment of the blastocyst to the uterine endometrium involves cellular growth and differentiation processes characterized by specific morphological and metabolic changes (Enders, 1976; Heald, 1976). Trophoblast-endometrium contact is soon followed by rapid disintegration and displacement of uterine luminal epithelium adjacent to the blastocyst (Fainstat, 1963; ElShershaby \& Hinchliffe, 1974). Numerous studies have shown that lysosomes are involved during cellular growth and differentiation processes (Moe \& Behenke, 1962; de Duve \& Wattiaux, 1966). Oestrogenic hormones have been said to labilize the membranes of cellular lysosomes and thus control cellular autophagy and lysis (Szego, 1975). $\beta$-Glucuronidase (EC 3.2.1.31) is a marker enzyme for cellular lysosomes and the present communication reports a histochemical study of $\beta$ glucuronidase distribution in the rat uterus during early embryo attachment, and on Day 5 of pseudopregnancy.

\section{Materials and Methods}

Adult, virgin, Wistar-strain rats were housed under controlled conditions of illumination $(14 \mathrm{~h}$ light $/ 10 \mathrm{~h}$ dark). Females with regular oestrous cycles were mated with fertile males and the presence of spermatozoa in the vaginal smear was considered as Day 1 of pregnancy. Pseudopregnancy was induced by ligating the oviducts of pregnant animals on Day 1 of pregnancy. On Day 5, at $22: 00 \mathrm{~h}, 16$ pregnant and 8 pseudopregnant females were given an i.v. injection of $0.5 \mathrm{ml}$ $0.5 \%$ Evans' blue in saline $(9 \mathrm{~g} \mathrm{NaCl} / \mathrm{l})$ and killed $15 \mathrm{~min}$ later. At autopsy, the uteri were checked for discrete blue bands which were found only in pregnant animals. Some blue band sites and inter-

* Reprint requests to Dr J. Sengupta, Department of Physiology, All India Institute of Medical Sciences, New Delhi 110029, India.

† Present address: Department of Physiology, University of Kansas Medical Center, College of Health Sciences \& Hospital, Kansas City, KS 66103, U.S.A. 
implantation areas from pregnant animals and whole uterine horns from pseudopregnant animals were fixed overnight in Holt's formol fixative at $4^{\circ} \mathrm{C}$ and then kept in $30 \%$ gum-sucrose solution for $24 \mathrm{~h}$ at $4^{\circ} \mathrm{C}$ for better preservation of lysosomes (Holt, Hobbiger \& Pawan, 1960; Holt \& Hicks, 1961). The rest of the blue band sites and uterine horns from pregnant and pseudopregnant animals were frozen immediately and kept at $-20^{\circ} \mathrm{C}$. Serial, $8 \mu \mathrm{m}$ thick transverse sections were cut at $-18^{\circ} \mathrm{C}$ from prefixed and freshly frozen uterine tissues. Uterine sections were studied for $\beta$ glucuronidase distribution by using two standard methods.

Sections from formol-fixed uterine horns were incubated in medium containing 6-bromo-2hydroxy-3-naphthoic acid-2-methoxyanilide- $\beta$-D-glucuronide (Sigma Chemical Co., St Louis, U.S.A.) as the substrate and freshly prepared hexazotized pararosanilin as the coupler in $0.2 \mathrm{M}$ sodium acetate buffer, $\mathrm{pH} 5$ at $37^{\circ} \mathrm{C}$ for $3 \mathrm{~h}$, according to the simultaneous coupling method described by Hayashi, Nakajima \& Fishman (1964). Unfixed sections, as well as fixed uterine sections, were also stained for $\beta$-glucuronidase by the post-coupling method described by Fishman

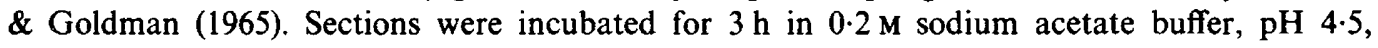
containing the above substrate, followed by coupling with Fast Garnet GBC (Sigma) in 0.1 Mphosphate buffer $\left(\mathrm{Na}_{2} \mathrm{HPO}_{4}: \mathrm{KH}_{2} \mathrm{PO}_{4}\right), \mathrm{pH} 7 \cdot 4$ at $4^{\circ} \mathrm{C}$ for $5 \mathrm{~min}$.

Potassium saccharate 1,4-lactone (Sigma), a specific inhibitor of $\beta$-glucuronidase (Chayen, Butcher, Bitensky \& Poulter, 1969) was used to check the specificity of the histochemical methods. Tissue sections, freshly frozen and prefixed, were incubated in substrate-containing medium with 0.1 M-potassium saccharate 1,4-lactone at $37^{\circ} \mathrm{C}$ for $3 \mathrm{~h}$.

A total of 40 positive blue bands, at least 20 serial sections from inter-implantation zones from pregnant animals and 20 serial sections from pseudopregnant horns were studied with a Leitz microscope by using a double-blind check for recording the distribution pattern of $\beta$-glucuronidase which was then graded \pm to ++++ depending on the intensity of the staining reaction. Representative tissue sections from each group were photographed.

\section{Results}

While staining for $\beta$-glucuronidase activity with the simultaneous coupling method the enzyme reaction product was visible as bright red granules of insoluble naphthol-rosanilin complex. In inter-implantation uterine regions, intense enzyme activity was observed mainly at the apical regions of the luminal epithelial cells; stromal tissues showed very high activity as did glandular epithelial cells and their secretions (Pl. 1, Fig. 1). However, a remarkable diversity in enzyme distribution was observed in uterine regions carrying an early implanting blastocyst. There was an overall low activity of $\beta$-glucuronidase in the blue-band areas, but uterine luminal epithelial cells closely apposed to the blastocyst showed a marked depletion of enzyme-rich vesicles in all such sections studied (PI. 1, Fig. 2). Such depletion was not observed in any other region of luminal epithelium. Stromal and glandular cells always exhibited a pronounced staining reaction in the inter-implantation zones. Pseudopregnant uteri, which were morphologically and functionally similar to the inter-implantation zones of the pregnant horns, exhibited similar intense activity of the enzyme. $\beta$-Glucuronidase-positive granules were present in stromal, glandular and luminal epithelial cells (PI. 1, Fig. 3). Sections stained by the post-coupling method using Fast Garnet GBC as the coupler exhibited the enzyme activity as faint blue granules but the distribution pattern was essentially the same as that observed for the simultaneous coupling method. However, much better intensity and clarity were obtained when sections were fixed in Holt's fixative and stained with hexazotized pararosanilin. To validate the method uterine sections from inter-implantation zones were incubated in substrate-containing medium in the presence of saccharolactone, a specific inhibitor of $\beta$-glucuronidase. A number of investigators have shown that saccharolactone specifically blocks $\beta$-glucuronidase activity in tissues (Chayen et al., 1969). The absence of any stained granules or enzyme reaction product indicated that the methods used were specifically localizing $\beta$-glucuronidase (Pl. 1, Fig. 4). 
PLATE 1
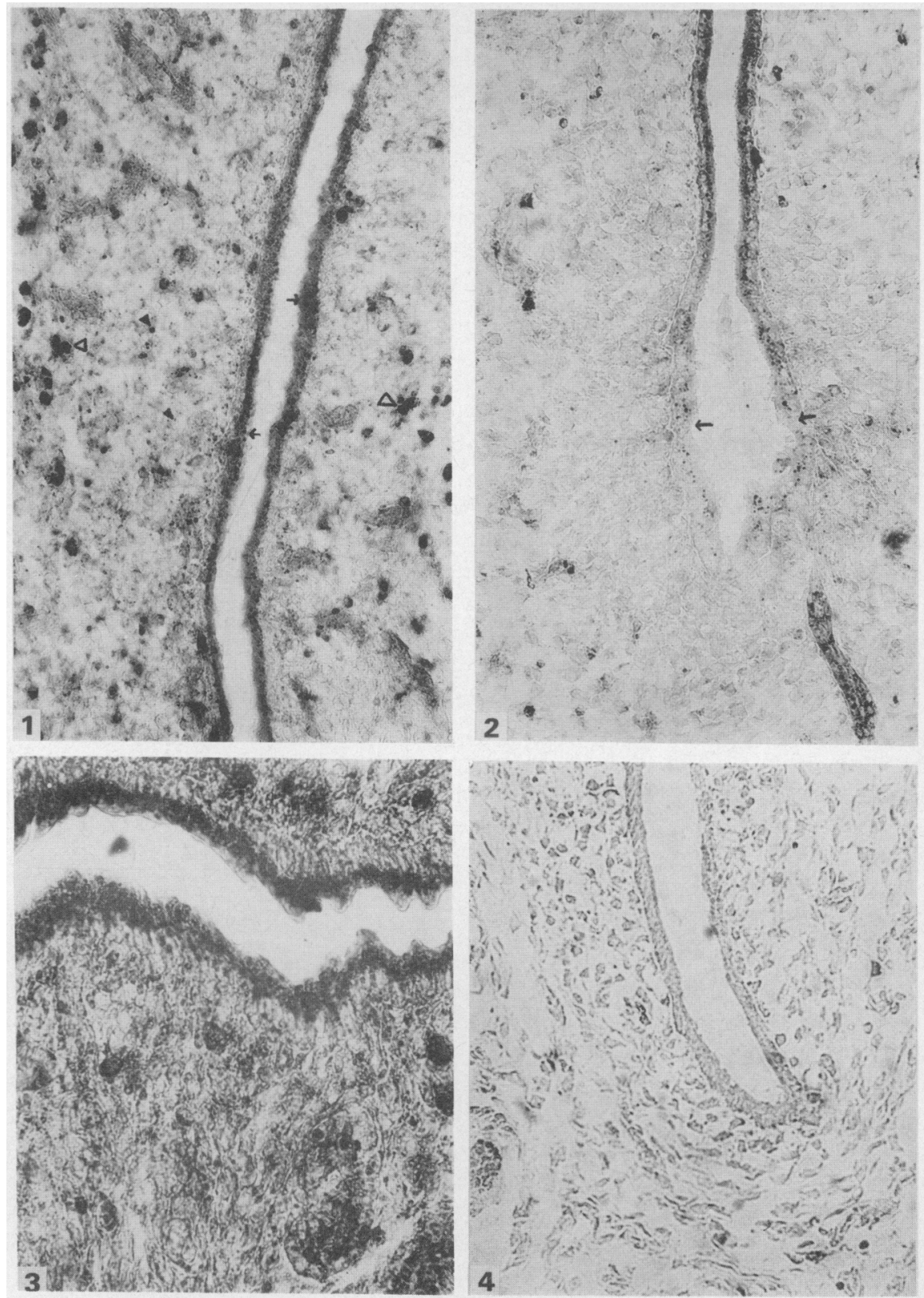

Fig. 1. Rat uterus on Day 5. of pregnancy showing a section obtained from an interimplantation zone exhibiting intense $\beta$-glucuronidase-positive granules in the apical regions of luminal epithelial cells $(\rightarrow)$, stromal $(\boldsymbol{\Lambda})$ and glandular $(\triangle)$ epithelial cells. $\times 720$.

Fig. 2. Uterine sections obtained from the implantation zone on Day 5 of pregnancy exhibiting positive staining for $\beta$-glucuronidase in stromal and glandular cells while the luminal epithelium $(\rightarrow)$ surrounding the blastocyst remains depleted of enzyme positive granules. $\times 720$.

Fig. 3. Rat uterus on Day 5 of pseudopregnancy showing the presence of intense $\beta$ glucuronidase-positive granules in the apical regions of the luminal epithelium and throughout the stroma and glandular epithelial cells. $\times 720$.

Fig. 4. Rat uterus on Day 5 of pregnancy showing absence of $\beta$-glucuronidase positive-staining reaction in the inter-implantation zone incubated in medium containing substrate plus saccharic acid 1,4-lactone. $\times 720$. 
Some of the blue band areas and inter-implantation zones from formol-fixed uterine horns were also stained by the post-coupling method to see whether fixation caused any deleterious effect on enzyme activity. There was no difference in the staining intensity and enzyme distribution pattern between pre-fixed and unfixed tissue sections.

\section{Discussion}

The first event in the attachment of the blastocyst in early implantation is its close apposition to the endometrium. This is soon followed by a stage of adhesion wherein specific moieties like terminal sugars may become exposed on fetal, as well as on maternal surfaces. Enders (1976) has suggested that a localization of the blastocyst on the uterus may be involved through specific glycosidases or peptidases. Leucylnaphthylamidase, an exopeptidase, has been implicated in blastocyst implantation of rabbits (Denker, 1977), rats, mice and hamsters (Sengupta, Roy \& Manchanda, 1979; Paria, Sengupta \& Manchanda, 1981; Sengupta, Paria \& Manchanda, 1981). In the rat and the mouse, adhesion accounts for phagocytosis of some of the endometrial cells which are sloughed. $\beta$-Glucuronidase present in cellular lysosomes and microsomal fractions (Barrett, 1977) is an exoglycosidase which plays a role in the catabolism of mucopolysaccharides by removing glucuronic acid residues from non-reducing terminals of oligosaccharides of heparin, chondroitin sulphate and hyaluronic acid (Buddecke \& Kresse, 1974; Glasser \& Conrad, 1979). These mucopolysaccharides are known to be components of cellular cementing substances and also of the basement membrane of cells, including those in the luminal epithelium. In the present study we observed a specific depletion of $\beta$-glucuronidase from luminal epithelial cells only at regions where there was contact with the blastocyst. Since this effect was absent in cells away from the implanting blastocyst as well as in non-decidualized pseudopregnant uteri, we suggest that mobilization or release of $\beta$-glucuronidase may occur as a cellular response to blastocyst-endometrial contact, and could be a localized effect initiated by the blastocyst.

This work was supported by the Indian Council of Medical Research and the Family Planning Foundation of India.

\section{References}

Barrett, A.J. (1977) Lysosomal enzymes. In Lysosomes; A Laboratory Handbook pp. 83-85. Ed. J. T. Dingle. North-Holland, Amsterdam.

Buddecke, E. \& Kresse, H. (1974) Mammalian enzymes degrading glycosamino glycans. In Connective Tissues, pp. 131-145. Eds R. Fricke \& F. Hartman. Springer-Verlag, New York.

Chayen, J., Butcher, R.G., Bitensky, L. \& Poulter, L.W. (1969) $\beta$-Glucuronidase. In A Guide to Practical Histochemistry, pp. 157-163. Eds J. Chayen, R. G. Butcher, L. Bitensky \& L. W. Poulter. Oliver \& Boyd, Edinburgh.

de Duve, C. \& Wattiaux, R. (1966) Functions of lysosomes. Ann. Rev. Physiol. 28, 435-492.

Denker, H.W. (1977) Implantation. In Advances in Anatomy, Embryology and Cell Biology, Vol. 53, Fasc. 5, pp. 8-120. Springer-Verlag, Berlin.

El-Shershaby, A.M. \& Hinchliffe, J.R. (1974) Cell redundancy in the zona-intact preimplantation mouse blastocyst: a light and electron microscopic study of dead cells and their fate. J. Embryol. exp. Morph. 31, 645-654.
Enders, A.C. (1976) Anatomical aspects of implantation. J. Reprod. Fert., Suppl. 25, 1-15.

Fainstat, T. (1963) Extracellular studies of uterus. I. Disappearance of the discrete collagen bundles in endometrial stroma during various reproductive states in the rat. Am. J. Anat. 112, 337-369.

Fishman, W.H. \& Goldman, S.S. (1965) A post-coupling technique for $\beta$-glucuronidase employing the substrate, naphthol-AS-BI- $\beta$-D-glucosiduronic acid. $J$. Histochem. Cytochem. 13, 441-447.

Glasser, J.H. \& Conrad, H.E. (1979) Chick embryo liver beta-glucuronidase. Comparison of activity on neutral and artificial substrates. J. biol. Chem. 254, 65886597.

Hayashi, M., Nakajima, Y. \& Fishman, W.H. (1964) The cytologic demonstration of $\beta$-glucuronidase employing naphthol-AS-BI-glucuronide and hexazonium pararosanilin. A preliminary report. J. Histochem. Cytochem. 12, 293-297.

Heald, P.J. (1976) Biochemical aspects of implantation. J. Reprod. Fert., Suppl. 25, 29-52.

Holt, S.J. \& Hicks, R.M. (1961) Studies on formalin 
fixation for electron microscopy and cytochemical staining purposes. J. Biophys. Biochem. Cytol. 11, 3145.

Holt, S.J., Hobbiger, E.K. \& Pawan, G.L.S. (1960) Preservation of integrity of rat tissues for cytological staining purposes. J. Biophys. Biochem. Cytol. 7, 383.

Moe, H. \& Behenke, O. (1962) Cytoplasmic bodies containing mitochondria, ribosomes and rough endoplasmic membranes in the epithelium of the small intestine of newborn rats. J. Cell Biol. 13, 168-171.

Paria, B.C., Sengupta, J. \& Manchanda, S.K. (1981) Involvement of lysosomal enzymes in mouse embryo implantation: effect of the anti-oestrogen, CI-628 citrate. J. Endocr. 90, 83-88.
Sengupta, J., Roy, S.K. \& Manchanda, S.K. (1979) Hormonal control of implantation: a possible role of lysosomal function in the embryo-uterus interaction. J. Steroid Biochem. 11, 729-744.

Sengupta, J., Paria, B.C. \& Manchanda, S.K. (1981) Effect of an oestrogen antagonist on implication and uterine leucylnaphthylamidase activity in the ovariectomized hamster. J. Reprod. Fert. 62, 437-440.

Szego, C.M. (1975) Lysosomal function in nucleocytoplasmic communication. In Lysosomes in Biology and Pathology, Vol. 4, pp. 385-447. Eds J. T. Dingle \& H. Dean. North-Holland, Amsterdam.

Received 8 September 1982 